\section{OCCUPIED HOLLAND}

\section{THE PUBEIC hEALTh}

BY

\section{BANNING, M.D.}

Chief Medical Officer of Public Health in the Netherlands

Before the war Holland ranked among the highest of nations regarding health. The death rate of babies was extraordinarily low. During the war the mortality rate increased regularly without, however, the "summer top" feared so much in former times. Immediately after the liberation, in the summer of 1945 , in spite of the good food supply the death rate of babies was so high that we could again speak of a "summer top." Many babies died within a few days with toxic appearances for which we could find no definite cause. Necropsy revealed no obvious reasons for the deaths. Per 1,000 born alive there died in the whole kingdom:

\begin{tabular}{|c|c|c|c|c|c|c|}
\hline & & & $\begin{array}{c}\text { Under } \\
1 \text { Week }\end{array}$ & $\begin{array}{l}1 \text { Week to } \\
1 \text { Month }\end{array}$ & 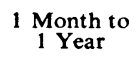 & Total \\
\hline $\begin{array}{l}1939 \\
1940 \\
1941 \\
1942 \\
1943 \\
1944(1\end{array}$ & $\begin{array}{cc}\ldots & \ldots \\
\cdots & \ldots \\
\cdots & \ldots \\
\ldots & \cdots \\
\text { lst } & \text { half-year) }\end{array}$ & $\begin{array}{l}\ldots \\
\cdots \\
\cdots \\
\cdots \\
\cdots\end{array}$ & $\begin{array}{l}15 \cdot 5 \\
16 \cdot 0 \\
16 \cdot 5 \\
14 \cdot 5 \\
14 \cdot 2 \\
15 \cdot 5\end{array}$ & $\begin{array}{l}4 \cdot 3 \\
5 \cdot 3 \\
6 \cdot 2 \\
4 \cdot 4 \\
6 \cdot 3 \\
7 \cdot 4\end{array}$ & $\begin{array}{l}13.9 \\
17 \cdot 9 \\
20.9 \\
18 \cdot 5 \\
19 \cdot 8 \\
20.7\end{array}$ & $\begin{array}{l}33 \cdot 7 \\
39 \cdot 1 \\
43 \cdot 4 \\
39 \cdot 8 \\
40 \cdot 3 \\
43 \cdot 5\end{array}$ \\
\hline
\end{tabular}

As regards infectious diseases Holland could be proud of its abnormally small number of cases. During the war diphtheria spread in a startling manner, and it was observed that the higher age groups were gradually being affected in large numbers. The epidemic started in 1942, in the southern provinces, and in the course of the next year or two spread over the whole country. In spite of the high figures recorded the number of cases is believed to have been still higher; for owing to poor communications many doctors were unable to report all the cases to the Inspector of Public Health.

Besides the steep rise in diphtheria there was an abnormal increase in the number of cases of typhoid fever. Already, in 1942 and 1943, cases were nearly five times as numerous as in pre-war years ; but in the first six months of 1945 the rise was still more startling. How could it be otherwise ? Families were herded together under extremely bad hygienic conditions. Thousands of houses and many water-pipes had been destroyed; medicines, disinfectants, and coal were scarce; and there was a total lack of soap. Fortunately the number of cases of typhoid is now declining. Scarlet fever also showed a rise, but not to the same degree as diphtheria and typhoid.

\begin{tabular}{|c|c|c|c|c|c|c|c|c|c|}
\hline & \multicolumn{5}{|c|}{ Reported Cases of Illness } & \multicolumn{4}{|c|}{ Reported Deaths } \\
\hline & & $\begin{array}{l}\text { Diph- } \\
\text { theria }\end{array}$ & $\begin{array}{l}\text { Scarlet } \\
\text { Fever }\end{array}$ & $\underset{\text { Fever }}{\text { Typhoid }}$ & $\begin{array}{c}\text { Acute } \\
\text { Polio- } \\
\text { myelitis }\end{array}$ & $\begin{array}{l}\text { Diph- } \\
\text { theria }\end{array}$ & $\begin{array}{c}\text { Scarlet } \\
\text { Fever }\end{array}$ & $\underset{\text { Fever }}{\text { Typhoid }}$ & $\begin{array}{c}\text { Acute } \\
\text { Polio- } \\
\text { myelitis }\end{array}$ \\
\hline $\begin{array}{l}1939 \\
1940 \\
1941 \\
1942 \\
1943 \\
1944 \\
1945^{*}\end{array}$ & $\begin{array}{l}\ldots \\
\cdots \\
\cdots \\
\cdots \\
\cdots\end{array}$ & $\begin{array}{r}1,273 \\
1,730 \\
5,437 \\
19,407 \\
56,790 \\
60,226 \\
49,730 \\
\end{array}$ & \begin{tabular}{|r|}
10,257 \\
8,841 \\
7,197 \\
12,694 \\
28,566 \\
22,470 \\
4,788 \\
\end{tabular} & $\begin{array}{r}172 \\
108 \\
161 \\
521 \\
531 \\
472 \\
4,848\end{array}$ & $\begin{array}{r}403 \\
111 \\
445 \\
196 \\
1,931 \\
1,180 \\
190\end{array}$ & \begin{tabular}{|c|}
75 \\
103 \\
213 \\
873 \\
2,515 \\
$?$ \\
$?$
\end{tabular} & $\begin{array}{r}24 \\
34 \\
35 \\
23 \\
128 \\
? \\
?\end{array}$ & $\begin{array}{c}25 \\
21 \\
27 \\
50 \\
76 \\
? \\
?\end{array}$ & $\begin{array}{r}25 \\
13 \\
22 \\
20 \\
222 \\
? \\
?\end{array}$ \\
\hline
\end{tabular}

* Provisional figures.

\section{Tuberculosis}

Tuberculosis causes much concern. All our strength will have to be exerted to combat this illness. The following table shows the rise of the total death rate of tuberculosis, as well as the death rate per 10,000 inhabitants and the increase per cent over 1939 .

\begin{tabular}{|c|c|c|c|}
\hline & $\begin{array}{l}\text { Total Deaths } \\
\text { from } \mathrm{Tb} .\end{array}$ & $\begin{array}{l}\text { Deaths per } 10,000 \\
\text { Inhabitants from } \mathrm{Tb} \text {. }\end{array}$ & $\begin{array}{c}\text { Increase over } \\
1939(\%)\end{array}$ \\
\hline $\begin{array}{llr}1939 & \ldots & \ldots \\
1940 & \ldots & \ldots \\
1941 & \ldots & \ldots \\
1942 & \ldots & \ldots \\
1943 & \ldots & \text { (1st } \\
19444 \text { (1)-year) }\end{array}$ & $\begin{array}{l}3,604 \\
3,881 \\
5,305 \\
5,555 \\
6,357 \\
3,789\end{array}$ & $\begin{array}{l}4 \cdot 10 \\
4 \cdot 37 \\
5 \cdot 92 \\
6 \cdot 13 \\
6 \cdot 99 \\
8 \cdot 38 *\end{array}$ & $\begin{array}{c}\overline{6} \cdot 6 \\
44 \cdot 4 \\
50 \cdot 0 \\
70 \cdot 5 \\
102 \cdot 0\end{array}$ \\
\hline
\end{tabular}

The fight against tuberculosis in Holland is carried on in Tuberculosis Consultation Bureaux. Holland is divided into districts, each having a consultation bureau with branch consultation bureaux in the smaller places, and it is possible for every citizen to visit them. Admission to the bureaux is free for everybody, from the poorest to the richest. The work of the consultation bureaux is to detect contact cases. The rise in tuberculosis can be noted not only from the mortality rate but from the increased number of cases which visit the consultation bureaux. In 1939 the new registrants were 60,377, in 1942122,795 , in 1943157,844 . In 1939 the consultation bureaux reported 13,560 cases of tuberculosis, in 194224,622 , and in 194327,981 .

A recent investigation of the bureaux showed that 50,000 cases of tuberculosis are known in the Netherlands. Thousands have to wait for months for admission to a sanatorium. All the sanatoria are filled to capacity, and it will take years to reach the favourable pre-war standard. Sanatorium and hospital facilities are being increased by providing wooden barracks, 300 of these having been ordered in Sweden. Every barrack will house 18 patients. Our greatest trouble is not lack of equipment but lack of medical and nursing personnel.

\section{A Period of Malnutrition and Starvation}

Malnutrition did not appear over the whole of Holland but only in the so-called B2 area or western district (the provinces of Utust: North Holland, and South Holland). In these provinces live half the population of the Netherlands-namely, 4 to 5 millions. The big cities-Utrecht, Amsterdam, Haarlem, Leiden, The Hague, and Rotterdam-are situated in the B2 area. When the Allied Forces marched into Nijmegen and Arnhem (September, 1944) and our Government in London ordered a universal railway strike the whole railway personnel obeyed: the Germans closed our non-agricultural provinces from the agricultural northern and eastern provinces as a reprisal. Seyss-Inquart laid an embargo on all the provisions which were transported from the north and east to the west, in order to maintain our already small rations. By this closing, and also because the Germans took away every means of transport, the western district was doomed to hunger.

The reserve of provisions in the western district was in such a state that the disaster already foreseen became a reality. The winter of 1944-5 was the winter of the notorious "hunger journeys." Officially no provisions were allowed to be transported, but it was often possible for people to break through the German line towards the north and the east. In that cold winter thousands of girls and women, on bicycles, without tyres or with a hand-cart, etc., badly dressed, with poor footwear, and starving, went in search of food. Journeys of 100 to 200 miles $(160$ to $320 \mathrm{~km}$.) were no exception. They came home laden with 30 to $50 \mathrm{~kg}$. of potatoes and some wheat, and could live for a few more weeks on that. Men between 16 and 50 years of age did not dare to show themselves in the street as they were constantly being rounded up and deported to Germany ; consequently our women and girls had to carry out this almost superhuman task.

During the winter the population of this $\mathrm{B} 2$ area lived without light, gas, heat, laundries, soap, or enough clothing, blankets, and food. Tulip bulbs and sugar-beet (officially distributed), plus some bread of very poor quality, were all we had to live on. After October, 1944, butter and animal fats were no longer distributed. As for other fats, from September, 1944 , to the end of March, 1945-7 months - 1.3 litres of oil was distributed per head, which means less than 0.2 litre per month. Officially there was also $100 \mathrm{~g}$. of cheese per month, but often meat coupons were of no value because no meat was available. The bread ration gradually decreased. In the course of the war it had come down from 2,200 to $1,800 \mathrm{~g}$. a week, then to 1,400 g., and later to $1,000 \mathrm{~g}$. ; in November, 1944, it was $800 \mathrm{~g}$., and in April, 1945, $400 \mathrm{~g}$. a week. Potatoes were rationed at $1 \mathrm{~kg}$. a week, but were hard to get.

As for the number of calories that were officially available per person, I submit the following figures:

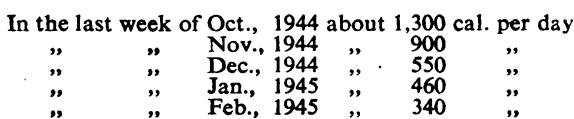


Owing to the close co-operation of the Catholic and Protestan Churches the so-called "latent" supplies present in the B2 area could be mobilized, and because of this activity many thousands of Dutchmen were able to hold on a little longer until, in the course of the first quarter of 1945, the Swedish Red Cross brought some relief. The number of calories could then be increased to 525 , and it was possible to distribute a food parcel of 700 calories a day for some weeks. But the last weeks of April, 1945, brought a severe cut-viz., to 400 calories a day. During the week before the liberation there was nothing left in the western district. Just for a few days a distribution of 230 calories a day, and then-no more. And in the very depth of this misery came the " finest dropping of the war," and Allied bombers threw out manna from Heaven. The "German" ration of 230 calories a day during the last days of April, 1945, was changed into the weekly "Allied" ration of :
$800 \mathrm{~g}$. bread
200 g. fat
$100 \mathrm{~g}$. butter
125 g. meat
$200 \mathrm{~g}$. beans and peas
$\frac{1}{2}$ tin bacon
2 bars of chocolate
kg. potatoes

\section{Consequences of the "Hunger Rationing"}

The first cases of death as a consequence of hunger were officially registered in the beginning of January, 1945. The death rate from hunger increased rapidly each week. Altogether at least 15,000 people died of hunger in B2 area, while about 80,000 cases of hunger oedema were known. First I will give a survey of the general death rate in the four big cities of the western district in the first half of 1939, 1944, and 1945.

\begin{tabular}{|c|c|c|c|c|c|c|c|c|c|}
\hline \multirow[t]{2}{*}{ Community } & \multicolumn{3}{|c|}{$\begin{array}{c}\text { General } \\
\text { Death Rate } \\
\text { 1st Half-year }\end{array}$} & \multicolumn{3}{|c|}{ Ratio $(1939=100)$} & \multicolumn{3}{|c|}{$\begin{array}{c}\text { Death Rate } \\
\text { per } \\
1,000 \text { Inhabitants }\end{array}$} \\
\hline & 1939 & 1944 & 1945 & 1939 & 1944 & 1945 & 1939 & 1944 & 1945 \\
\hline $\begin{array}{l}\text { Amsterdam } \\
\text { Rotterdam .. } \\
\text { The Hague . } \\
\text { Utrecht .. }\end{array}$ & $\begin{array}{r}3,655 \\
2,616 \\
2,419 \\
776\end{array}$ & $\begin{array}{l}4,399 \\
3,260 \\
2,940 \\
1,112\end{array}$ & $\begin{array}{l}9,735 \\
7,827 \\
6,458 \\
2,065\end{array}$ & $\begin{array}{l}100 \\
100 \\
100 \\
100\end{array}$ & $\begin{array}{l}120 \cdot 2 \\
124 \cdot 6 \\
121 \cdot 5 \\
143 \cdot 2\end{array}$ & \begin{tabular}{|l|}
$266 \cdot 3$ \\
$299 \cdot 2$ \\
$267 \cdot 0$ \\
$266 \cdot 1$
\end{tabular} & $\begin{array}{l}4 \cdot 60 \\
4 \cdot 25 \\
4 \cdot 86 \\
4 \cdot 67\end{array}$ & $\begin{array}{l}5 \cdot 69 \\
5 \cdot 39 \\
6 \cdot 50 \\
6 \cdot 54\end{array}$ & $\begin{array}{l}12 \cdot 61 \\
12 \cdot 94 \\
14 \cdot 38 \\
12 \cdot 15\end{array}$ \\
\hline
\end{tabular}

The death rate was greatest in February and March, when food rations were smallest. In the smaller towns the death rate increased in almost the same ratio as in the big cities, while the rate in the country districts, although increasing, was not so serious as in the towns. It is remarkable that in the big cities the death rate of men was much higher than the death rate of women. It is not clear to what causes the higher death rate among men was due. Heavier work was not a likely cause, for many factories and offices were either forced to a standstill or had to carry on with a greatly decreased working time. The women did wonders in the way of physical effort: it was they who went out for food under the most unfavourable conditions. Moreover the high male death rate occurred in all age groups, including infants and the groups over 50 years. As hundreds of thousands of men had already been deported to Germany, and others had "gone underground"-i.e., they hid somewhere in the country - the death rate for men might have been still more unfavourable. It is now known that $75 \%$ of those who died from malnutrition were men.

Death Rate from Malnutrition in The Hague in 1945

\begin{tabular}{|c|c|c|c|c|c|c|}
\hline \multirow[b]{2}{*}{ Age Group } & \multicolumn{3}{|c|}{ Total Death Rate } & \multicolumn{3}{|c|}{$\%$ of Dead from Malnutrition } \\
\hline & $\begin{array}{c}\text { 1st } \\
\text { Quarter, } \\
1945\end{array}$ & $\begin{array}{c}\text { 2nd } \\
\text { Quarter, } \\
1945\end{array}$ & $\begin{array}{l}\text { Half- } \\
\text { year, } \\
1945\end{array}$ & $\begin{array}{c}\text { 1st } \\
\text { Quarter, } \\
1945\end{array}$ & $\begin{array}{c}\text { 2nd } \\
\text { Quarter, } \\
1945\end{array}$ & $\begin{array}{l}\text { Half- } \\
\text { year, } \\
1945\end{array}$ \\
\hline 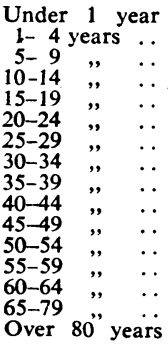 & $\begin{array}{r}28 \\
14 \\
5 \\
0 \\
3 \\
10 \\
12 \\
13 \\
16 \\
43 \\
62 \\
90 \\
153 \\
154 \\
586 \\
130\end{array}$ & $\begin{array}{r}24 \\
11 \\
0 \\
2 \\
1 \\
4 \\
7 \\
9 \\
10 \\
20 \\
29 \\
36 \\
62 \\
93 \\
373 \\
93\end{array}$ & $\begin{array}{r}52 \\
25 \\
5 \\
2 \\
4 \\
14 \\
19 \\
22 \\
26 \\
63 \\
91 \\
126 \\
215 \\
247 \\
961 \\
223\end{array}$ & $\begin{array}{r}2.12 \\
1.06 \\
0.38 \\
- \\
0.23 \\
0.76 \\
0.91 \\
0.98 \\
1.21 \\
3.26 \\
4.70 \\
6.83 \\
11.60 \\
11.67 \\
44.43 \\
9.86\end{array}$ & $\begin{array}{r}3.09 \\
1.41 \\
0 \cdot 26 \\
0.13 \\
0.51 \\
0.90 \\
1.16 \\
1.28 \\
2.57 \\
3.74 \\
4 \cdot 63 \\
8.00 \\
12.00 \\
48.32 \\
12.00\end{array}$ & $\begin{array}{r}2.48 \\
1 \cdot 19 \\
0 \cdot 24 \\
0 \cdot 10 \\
0 \cdot 19 \\
0.67 \\
0.90 \\
1.05 \\
1.24 \\
3.00 \\
4.35 \\
6.01 \\
10.26 \\
11.80 \\
45.87 \\
10.65\end{array}$ \\
\hline Total & 1,319 & 776 & 2,095 & $100 \%$ & $100 \%$ & $100 \%$ \\
\hline
\end{tabular}

What strikes one when examining the death rate from malnutrition is the fact that persons in the older age groups were those mostly affected. This is exemplified in the figures for The Hague given in the preceding table. Consequently in The Hague as many as $84 \%$ of the deaths due to malnutrition were of persons over 50 years, while $56 \%$ were of those over 65 . In the age group 5-35 years there were very few deaths-in The Hague only $3.14 \%$ of the total. The growing-up period of 5-19 years came out exceedingly well, whereas the percentage for the infants was fairly high. I dare not say to what degree the combination of hunger plus cold played its part in this trouble. Though I give only the figures for The Hague, those for the other big cities in the western district (Rotterdam, Amsterdam, Haariem, Leiden, Utrecht) show exactly the same picture. The western district paid heavily for this war, suffering as it did from so severe a famine.

\section{Relief Measures}

And now for the question how we combated the hunger. On May 3, 1945, some days before the German Headquarters capitulated, consequently when the war was still going on in B2 area, four Allied officers entered that area. It was the "Advisory Committee" for the "Special Feeding Teams," who were ready in the southern part of our country to help B2 in its great need. The leader of this "Advisory Committee " was Sir Jack Drummond (England); the others were Dr. Leach (U.S.A.), Dr. Beattie (England), and Dr. Loutit (England), together with myself. The 50 special feeding teams (each of them with a doctor as its leader) were distributed over the most threatened places in B2. Their activities started in the hospitals; later on they shifted to the polyclinics. The teams brought specially prepared food, together with laboratories and instruments. At the same time large quantities of food were dropped on the aerodromes and loaded ships came up "Waterweg " to Rotterdam, while from the east via the province of Gelderland, thousands and thousands of tons were brought by trucks. The result of all this was that by May 15 there was a considerable decrease in the number of deaths from malnutrition-a decrease which continued till the beginning of August, when it disappeared altogether.

\section{CLINICAL IMPRESSIONS*} BY

\section{DR. HENRIETTE A. LOHR} Amsterdam

Whereas in Paris hunger osteopathy was seen as early as 1942, the first case of osteomalacia caused by food deficiency in Holland was described in March, 1943. Afterwards there were many cases of hunger osteopathy.

The chief symptoms in hunger osteopathy are pain and stiffness of the back, the lower limbs, the feet, and now and again also in the arms and ribs. The patients move about in a curious stiff way, and when rising out of a chair have to heave themselves up by their hands. Coughing and sneezing may be painful. In some cases, as the complaint was thought to be of rheumatic origin, gold therapy had been tried, but in vain. On $x$-ray investigation one finds translucent notches or bands of decreased opacity, so-called looser zones, where the bone has been replaced by osteoid. They are located chiefly in regions of stress and strain. In some cases there are definite fractures with callus formation. Hunger osteopathy is regarded by certain authors as " the result of a combined deficiency of multiple food factors, of which animal protein might be one and of which vitamin $D$ is probably the most important. If untreated, hunger osteopathy develops progressively into typical osteomalacia. Twenty-two of our cases occurred in women. We are inclined to ascribe this peculiar sex distribution to a difference in food habits between men and women, rather than to hormonal distinction between the sexes. Generalized osteoporosis is often present, but may be slight in early cases. All our cases improved with rest in bed, a full diet especially rich in animal protein and calcium (milk), with extra vitamin $D$ by mouth or by injection. The patients lost their pains within two weeks. $X$-ray examination demonstrated objective improvement within two months. It is our impression that vitamin D

* Abridged from an address to the London Association of the Medical Women's Federation, Sept. 24, 1946. 
was the most important therapeutic agent. It made no difference whether the vitamin was given by mouth or by injection."

From 1944 children were seen with Barlow's disease, which had become unknown in Holland, and rickets was increasing rapidly. Pellagra was observed in psychiatric patients from 1941 , and afterwards cases occurred in mental hospitals, though they were fewer than had been anticipated. There were, however, many cases of perniosis, which probably had some connexion with nicotinic acid deficiency, and mouth and tongue sores, which undoubtedly had. The same can be said of beriberi: we did not see many definite cases, but there was an unusual number of patients with polyneuritis, and there still is. From 1942 we all had polyuria, especially at night, quite frequently amounting to more than 3 litres a day. It must be considered as a latent oedema.

Food poisoning by mushrooms and by beech-nuts was seen from 1942. Up to 1943 there had been 223 cases of the latter. Beech-nut poisoning is characterized by intestinal troubles, severe headache, difficulty in breathing, a cloudy effect on the brain, and in some cases a rabies-like condition: it can be avoided by removing the germ of the nuts. The illness passes in a few days and is never dangerous. Botulism brought about a state resembling myasthenia gravis.

Partly as a result of the coarseness of the food and partly owing to psychic strain, cases of ulcer of the stomach and of the duodenum increased. Stolte and Beaumont state that at the Onze Lieve Vrouwe Gasthuis at Amsterdam during the 44 months from January, 1936, to September, 1939, there were 392 ulcer cases in the wards, whereas during the 46 months from September, 1939, to July, 1943, there were 633. The number of ulcers of the lesser curvature was relatively higher than before the war and the perforations had increased considerably.

Treatment of diabetes mellitus became very difficult on account of the lack of insulin and of suitable food. All diabetics except the very severe cases had to do without insulin and had to be reduced to hunger diets. During the "hunger winter" these were symptom-free, though sugar-beet was their principal food. Afterwards they suffered severe relapses. Lack of fuel during the very cold winters of 1941 to 1944 was the cause of a much higher incidence of rheumatic diseases and perhaps also of nephritis. The latter, however, was apparently contagious, like trench nephritis during the war of 1914-18. It was characterized by severe uraemia and oedema, with a blood pressure that was only moderately high. Blood pressure in general had a tendency to be lower than usud, probably because of undernourishment.

\section{Poliomyelitis and Diphtheria}

During 1943 there was a bad epidemic of poliomyelitis and its contagiousness was clearly demonstrated in a home for children. Most of our bacteriologists now adhere to the theory of faecal infection. Lack of soap may have influenced this epidemic. We always have had some cases, mostly during the summer months: in Amsterdam they amounted to 8 or 9 a year. During 1943 in Amsterdam alone 635 cases were notified, and there probably were many more, as the abortive form with intestinal trouble, headache, and moderate temperature is not easily recognized and cannot be detected from the specific reactions in the spinal fluid, as during an epidemic these reactions are positive in many who haven't been manifestly ill. These persons must all have undergone infection and gained immunity as a consequence. In the course of one year the population may be said to be "durchseucht," as the Germans call it. To be sure, in the next year there were only 51 new cases.

Already in 1941 the figures for diphtheria were showing a tendency to rise. In Amsterdam new cases were shown to belong to the intermedius and not to the local mitis strain. The next year brought a very bad epidemic, and this time it was caused by the gravis strain, which had been imported from Germany. From a mean figure of 100 cases a year in Amsterdam, we had nearly 8,000 cases in 1944, among which were many severe infections, with early death from toxaemia or paralysis even after many months. The infection, moreover, was made worse by the lack of serum and could not be controlled until after our liberation, when we were able to obtain the potent new British sera. During this epidemic many adults fell ill, even those who had had diphtheria before, as the former mitis infection gave no protection against this new strain. This epidemic therefore proved fatal to many adult people as well as children.

\section{Hunger Oedema}

The official report of the percentage of people with hunger oedema during the spring of 1945 has not yet been published. Most of the population were showing some slight degree of oedema, and all of us had nocturia. In many people the oedema did not become manifest until the summer, when we had salt again. The oedema still has a rendency to return, perhaps because our food is poor in protein. Though there is a predilection for the lower parts 'of' the body, other parts may become involved through various causes-for instance, local infection or mechanical irritation. A very frequent location was the face. In oedema formation the protein content of the blood plasma is not the only factor, for in some cases of oedema the blood protein was not lowered at all. Prof. Formyne is of the opinion that hunger oedema has some features in common with nephritic oedema as regards distribution, the possible normality of blood proteins, and the lack of a rise in venous pressure.

With regard to the last feature, however, Stolte has pointed out that the tissue pressure is very much lowered as a consequence of the loss of fat and part of the muscle tissue. There is a curious contrast between the dry leathery skin in some parts, which is loose and can be lifted up in big folds, and the solid oedema in other parts. Venous pressure cannot be high with such a low tissue pressure. In another respect there is a difference between the nephritic oedema and hunger oedema, as the latter is low in protein. Renal function was normal and there were no indications of cardiac insufficiency. Most people had a very pronounced bradycardia and lowered blood pressure. Damage to the capillary wall must be an important factor, as the Rumpel-Leede phenomenon was always present. Low tissue pressure is another factor, and lowering of blood albumin plays a part in some cases.

Dr. Adelsberger, from her experiences in German camps. made a distinction between two types of starvation-a dry form and one with oedema. We had the same experience in Holland, inasmuch as between February and May, 1945, people collapsed in the streets and died from starvation, with very low body temperatures, showing little or no oedema, and sometimes not seeming so very thin either, the latent oedema having taken the place of the intertissue fat. During this cold winter body temperatures of $27-29^{\circ} \mathrm{C}$. were not uncommon in these people and most of them died. It proved very difficult to raise these low temperatures. After our liberation the number of patients with manifest oedema increased considerably. Even with a very poor diet and rest they would sometimes lose their oedema in a short time, showing a diuresis of 3-5 litres a day. All of these patients had anaemia, sometimes in a macrocytic form, which was not cured either by iron or by liver. It was not the deficiency anaemia of Lucy Wills, but rather an aplastic form, the bone marrow showing very little activity. It responded to proper feeding very slowly, and then often changed into a hypochromic anaemia, which reacted to iron.

Psychic factors were an extreme lassitude and apathy, with considerable irritability. Anxiety states and psychosis were sometimes seen. Many elderly people took to their beds and died because they could not be bothered with the trouble of standing in queues to get a pint of thin soup. Others were frozen to death from lack of fuel. The Bureau of Churches has done much good work in seeking out and feeding these people.

Polyneuritis was and is still a common disease. In some rare instances there was a neuritis of the optic nerve with central blindness, weakness of the muscles, considerable muscle irritability, and a tendency to cramps, which persists in some. The blood calcium was lowered in many instances. Chvostek's sign and Trousseau's phenomenon were only occasionally present.

Many people had intestinal troubles, which were aggravated by the diet of sugar-beet and tulips. For some time we had half a loaf of bread and $4 \mathrm{~kg}$. of potatoes for the whole week 
and nothing more, these rations amounting to 300 calories a day. Though people went far afield to get food, they often returned with little or nothing, and were weakened by days of walking or cycling.

People who collapsed, standing in queues or going about the little work that was yet done, did not show orthostatic hypotension, but a low blood sugar. They swayed some time before actually falling down, sweated, and seemed completely dazed. In extreme cases of starvation hunger disappeared and food was refused because of difficulties in swallowing. In elderly persons death from cold was caused by lack of fuel, but ast the same time there may have been a deficiency of the thyroid gland as a result of starvation, as at necropsy the gland was found to be small and leathery. Basal metabolism was lowered in most people from 20 to $30 \%$. Strange as it may seem during a period of hunger, in cases of hypothermia some advocated the use of thyroid.

A curious feature was that some girls and young women got fat on a diet totally insufficient. This condition is probably a mixture of myxoedema and hunger oedema, but the oedema is not demonstrated very easily. It is difficult to cure this condition with our present food supply. Even now there is a serious lack of protein and a relative abundance of carbohydrates. These patients are not benefited very much by thyroid extract. They complain of weakness and severe headaches, which sometimes are made worse by thyroid therapy. Treatment of starvation with or without oedema has consisted in rest in bed and a diet of skimmed milk with glucose and vitamins. Very slowly the food intake has been raised. Kaolin, lactic acid, charcoal, and opium proved of value in the treatment of intestinal trouble. Intravenous therapy of casein preparations, amino-acids, and blood or plasma transfusions did not prove of much value.

We have learned some things during this hunger period. Even those who didn't get oedema have experienced a curious change in their outlook and behaviour, which varied from complacency and apathy to irritability. Formerly we may have scoffed at the poor for not being able to grasp the many opportunities 'which life offers to better their conditions. We never realized the fundamental significance of food. People who have been starved many times, like the Indians, are apt to have an outlook; on life and a standard of behaviour different from those of more fortunate ones. There is to-day nothing perhaps of more importance than the effort to obtain food control for the whole world, and nothing more necessary than to improve upon it until it is possible to provide adequate food for all countries and for every man and woman and child of the community. Not until this is achieved will it be possible to assess the intellectual and moral qualities of the various races, or to expect their willing and active co-operation towards pacification and unification of the world.

\section{THE PASTEUR EXHIBITION}

The United Nations Educational, Scientific, and Cultural Organization (Unesco) organized last year, as part of its International Month, an exhibition commemorating Pasteur, which was shown at the Palais de la Découverte in Paris. This has now, through the co-operation of the Cultural Relations Department of the French Foreign Office and our Ministry of Works, been brought to the Science Museum, South Kensington, where it will be on view free until May 26. It was opened on April 9 by M. Réné Varin, the Cultural Counsellor to the French Embassy in London, who said that perhaps Pasteur's most striking quality was his patience, which exemplified the aphorism that genius is a capacity for taking infinite pains. Throughout his life he had never set himself a plan of research but had let problems come to him. The work which had first made him famous has led to his revolutionary discoveries on the nature of fermentation, by which he had disproved the traditional notion of spontaneous generation. From that he had passed to diseases of silkworms, anthrax, fowl cholera, swine fever, and rabies. His love of science and humanity was entirely altruistic. He was completely indifferent to the standing of the persons he helped, and although he had had many opportunities of self-enrichment he had neglected them. He was an intensely religious man and spent the night awake and at prayer before he first used his antirabic serum on a human patient.

France was naturally proud of Pasteur, the more so because his qualities of tenacity and patience were relatively rare among Frenchmen. These very qualities had perhaps served to link him more closely with his English hosts, for whom he had performed some of his most notable work. Visitors would see an admirably penned letter in French from Lord Lister to Pasteur, and another in which Pasteur acknowledged the inspiration he had received from the works of Lister and Jenner. The intimate connexion of these three great men, in their will to help humanity, was a strong tie between their two countries.

Sir Henry Dale regretted that His Excellency the French Ambassador, M. Massigli, could not be present, but thanked him, M. Varin and his colleagues, and M. André Léveillé, Director of the Palais de la Découverte, who was directing the temporary installation of the exhibition in London. Dr. $\mathrm{H}$. Shaw, the director of the Science Museum, had co-operated in arranging for this display, to the great gain in instruction and interest of all who visited it. An important addition had been made by the loan of a collection from the Wellcome Historical Medical Museum, and by the specimens lent by the Dewar Laboratory at Edinburgh and Messrs. Whitbread. The exhibition gave visitors the opportunity and privilege of recalling vividly, with intimacy and detail, the life and scientific achievement of one of the greatest of all the distinguished sons of France and one of the outstanding figures in the science of all the world in all the four centuries since modern science had begun. No adequate estimate could be made of the value in human health, happiness, and prosperity of all Pasteur's discoveries. His marvellously consistent career, which the exhibition served to teach and reinforce, pointed, however, one lesson: Pasteur did not set out on his life's work with even a thought that it would lead to discoveries revealing the nature of fermentation, of putrefaction, or, eventually, of infectious diseases as due to specific living micro-organisms; he did not even start as a biologist, but as a mineralogist and crystallographer. His first great discovery, which at the early age of 34 had won for him the Rumford Medal of the Royal Society, had been of the crystallographic and optical asymmetry of the two kinds of tartaric acid. From that discovery he had followed the natural lead of his genius, to recognize the' connexion between such asymmetry and the chemical activities associated with life. Thus in logical and unbroken sequences he had come to discover living organisms as the causes of fermentation, putrefaction, and infectious diseases, to expose the fallacies in all the appearances which had led men to believe in spontaneous generation, and to lay the scientific foundations of all our knowledge of specific immunity. These discoveries had led to revolutionary changes in the conditions of civilized existence and represented an almost incredible sum of achievement for one man's life ; but they represented the achievement of one who throughout his life remained a single-minded seeker for truth for its own beauty and interest, who had humbly accepted Nature's answer to his inspiring questions and faithfully followed the clue wherever it led.

Sir Henry concluded by saying he hoped the exhibition would strengthen still further the ties of intellectual and cultural sympathy and of scientific comradeship between France and Britain, and that, as in Pasteur's day, so now the work of scientists would help both peoples to rise above the losses, injury, and deprivations which a greater and even more cruel war had left in its train.

Dr. H. Shaw, Director of the Science Museum, moved a vote of thanks to the French authorities for placing the exhibition at the disposal of the Science Museum and for the strenuous work they had done to make it ready, and to the other contributors to its success.

The exhibition includes several portraits of Pasteur, his masters, disciples, friends, and colleagues ; enlarged photographs of Strasbourg, Lille, and other towns and districts where he lived; pictures of the Ecole Normale where he investigated molecular dissymmetry, of Salins and Montenvers where he worked on spontaneous generation and other places made famous by association with him, and of members of his family. 